\title{
BANK SYARÎ'AH DAN TAKÂFUL (Sebuah Kajian Evaluatif-Reflektif atas Perkembangan Bank Syarî'ah dan Takâful di Indonesia)
}

\author{
Sofyan Hadi \\ (Sekolah Tinggi Agama Islam Negeri STAIN Jember, jln. Mangli Jember, \\ email: sofy_hadi@gmail.com)
}

\begin{abstract}
Abstrak
Islam menjiwai dan mewarnai perilaku manusia dalam berpikir, bersikap maupun bertindak dengan batas-batas yang telah di tetapkan, dalam rangka pengabdian kepada Allah swt. Setelah melalui perdebatan sengit selama berabad-abad tentang perilaku bunga uang (ribâ, interest) dalam menentukan perilaku ekonomi manusia, antara diharamkan atau dibolehkan, kini muncul di hadapan kita keputusan di mana terbuka jalan bagi yang mengharamkan bunga dan bagi yang membolehkan atau bahkan mengharuskannya dengan konsep yang lebih Islâmî dan dapat diterima oleh berbagai pihak terutama mayoritas penduduk Indonesia yang notabene beragama Islam dengan apa yang dikenal sebagai bank syarî'ah dan takâful (asuransi Islâm). Melalui kedua lembaga inilah kita berharap dapat menyaksikan pada satu saat terwujudnya "gurita" ekonomi umat yang dahsyat, apabila terjadi kerjasama mudlarabah di tingkat kelembagaan ekonomi syarî'ah (BMI, BSI, BPRS, BMT dan STI) dengan berpedoman pada ta'âwan $\hat{u}$ 'alâ al-birr wa al-taqwâ, wa lâ ta'âwwan û alâ al-itsm wa al-'udwân. Kerjasama ini hendaklah profesional. Untuk itu perlu dibangun manajemen yang Islâmî, yang didukung dengan sumber daya terampil, yang bekerja dengan keyakinan dan teguh dalam pendirian serta memiliki moral atau akhlaq yang luhur.
\end{abstract}

\begin{abstract}
Islam inspires human behavior in thinking, behaving, and acting with the specified limits in dedication to Allah. After a fierce debating for centuries about ribâ interest in deciding human activities of economy, whether it is allowed or forbidden, now it appears deciding for those who forbid interest and also for those who allow or even require it by using more Islamic concept in which it can be accepted by all people especially indonesian majority whose religion are Islam, which
\end{abstract}


is so called syarî'ah bank and takâful (Islamic asuransi). Through these institutions, we hope someday we can see the creating "gurita" of great people's economy, if it will happen a mudlarabah cooperation in institution level of syarî'ah economy (BMI, BSI, BPRS, BMT and STI) based on ta'âwanû 'alâ al-birr wa al-taqwâ, wa lâ ta' âwan û alâ al-itsm wa al-'udwân. This cooperation should be proffesional. Therefore, it needs to have Islamic management, supported by competent human resources, that can work with certainty and firmness in standing and having moral or noble character.

Kata-kata Kunci

bank syarî'ah, takâful, bunga bank, dan mudlarabah.

\section{Pendahuluan}

Runtuhnya sistem moneter secara makro harus disadari bahwa salah satu penyebabnya adalah karena uang bukan lagi berfungsi sebagai alat tukar (media of change), akan tetapi sudah menjadi komoditas. Padahal dalam Islam, uang hanyalah sebagai alat tukar jasa dan barang. Sistem moneter yang harus dijalankan menurut Islam meliputi dua hal: Pertama, otoritas moneter harus diyakinkan agar mengembalikan posisi uang sebagai alat tukar, bukan komoditas. Kedua, menghindari jual beli uang dalam bentuk apapun termasuk valuta asing.

Bertahannya bank syarî'ah terhadap krisis mata uang maupu kebijakan uang ketat, karena bank Islam sangat menghindari jual beli uang dan uang tidak dijadikan sebagai komoditas. Jika masih ada, dampaknya hanya pada penundaan angsuran. Bank syarî'ah sistem pembiayaannya berdasarkan riil pada nasabah, tidak meletakkan pembiayaan pada sektor semu atau yang bersifat spekulaif.

Pada saat sekarang ini, ekonomi Islam telah memasuki pengembangan dengan pendekatan yang lebih integratif dan sophisticated untuk membangun keseluruhan teori dan praktek ekonomi Islam terutama lembaga keuangan dan perbankan yang menjadi indikator ekonomi umat.

Dengan disahkannya Undang-undang Perbankan No. 10 tahun 1998, telah memberikan landasan yang luas dan kuat bagi berdirinya perbankan syarî'ah di Indonesia. Selama kurun waktu 6 tahun, yaitu sejak tahun 1992 hingga 1998 hanya terdapat satu bank Islam, di 
Indonesia yaitu Bank Muamalat Indonesia (BMI). Dengan undangundang baru ini, dimungkinkan keleluasan dari segi dasar pendirian bank, sehingga dalam kurun waktu tiga tahun telah bermunculan beberapa bank syarî'ah yang baru, seperti Bank Syari'ah Mandiri, Bank IFI cabang usaha syarî'ah, Bank Bukopin cabang usaha syarî'ah, Bank Jabar cabang usaha syarî'ah dan BNI'46 Syarî'ah. Dimungkinkan di masa mendatang akan bermunculan lebih banyak lagi dari bank konvensional yang berminat membuka cabang syarî'ah atau mengkonversikan salah satu anak perusahaannya menjadi fully syarî'ah implemened. ${ }^{1}$

Selain perbankan syarî'ah, juga bermunculan lembaga keuangan Islam di Indonesia yang bergerak dalam bidang asuransi yaitu asuransi takâful. Induk perusahaannya bernama PT. Syarikat Takaful Indonesia, dengan nama anak perusahaannya PT Asuransi Takaful Keluarga dan PT Asuransi Takaful Umum. ${ }^{2}$ Perusahaan asuransi takâful ini juga mengalami pertumbuhan yang luar biasa, seiring dengan kesadaran umat Muslim untuk menawarkan solusi alternatif persoalan ekonomi bangsa Indonesia.

Berdirinya asuransi takâful di Indonesia seakan mendapat inspirasi atas berdirinya perbankkan syarî'ah yang didasarkan atas Undang-undang No. 7/1992. Dengan berdirinya perbankan syarî'ah tersebut telah memunculkan kebutuhan akan kehadiran asuransi takâful di Indonesia. Pada 27 Juli 1993, ICMI melalui Yayasan Abdi Bangsa bersama BMI dan perusahaan Asuransi Tugu Mandiri bersepakat untuk mendirikan asuransi takâful, dengan menyusun Tim Pembentukan Asuransi Takâful Indonesia (TEPATI). Tim ini telah merealisasikan berdirinya PT. Syarikat Takaful Indonesia sebagai Holding company dan dua anak perusahaannya, yaitu PT Asuransi Takaful Keluarga (Asuransi Jiwa) dan Asuransi Takaful Umum (Asuransi Kerugian).

1 Iwan Triyumono, "Ekonomi Islam, Ekonomi Riil", Jurnal Ulumul Qur'an, Vol. VII No. 2 (1996).

2 Syarikat Takâful di Indonesia berdiri sejak tahun 1994, yang diprakarsai oleh kerja sama antara ICMI, BMI, dan Asuransi Tugu Mandiri. Lihat Redaksi Ulumul Qur'an, “Syarikat Takaful Indonesia”, Jurnal Ulumul Qur'an, Vol VII No. 2 (1996), hlm. 35-57. 


\section{Perkembangan Perbankan Syar'iah di Indonesia}

Pada bulan Agustus 1998 di Singapura, telah diselenggarakan Islamic Bank Conference, yang menunjukkan bahwa lembaga keuangan Islam telah mengalami perkembangan yang pesat, yaitu mencapai 200 buah, di antaranya 160 berupa bank dan sisanya berupa lembaga keuangan non-bank. Potensi pasar yang besar bagi kegiatan pebankan Islam, telah membuka cakrawala baru bagi negara-negara "non-Muslim" untuk membuka Islamic division pada bank tersebut, seperti Citibank, Chase Mahattan Bank, ANZ Bank dan Jardine Fleming.

Di Eropa yang sebagian besar masyarakatnya non-Muslim, bank syarî'ah telah berkembang dengan pesat, terutama di London. Di negara-negara Eropa, perbankan syarî'ah memperoleh dasar untuk tumbuh dengan baik, karena tingkat inflasi dan tingkat bunga Bank yang rendah. Bank-bank Islam memang lebih dapat berkembang di negara-negara dengan tingkat inflasi dan tingkat bunga bank yang rendah dibandingkan dengan negara-negara dengan tingkat inflasi dan tingkat bunga bank yang tinggi. ${ }^{3}$

Adapun perkembangan perbankan syarî'ah di Indonesia dapat dilihat sejak diberlakukannya Undang-undang No. 7/1992. Undangundang ini telah memberikan peluang bagi berdirinya perbankan syarî'ah. Berdirinya Bank Muamalat Indonesia, yang kemudian diikuti berdirinya bank-bank pengkreditan rakyat (BPRS), merupakan sejarah baru bagi umat Muslim Indonesia. Namun demikian, keberadaan perbankan syarî'ah di Indonesia masih menunjukkan kondisi yang perlu perbaikan, baik operasionalnya maupun secara enviromental (makro). Sebagian besar BPRS masih menunjukan kinerja operasional yang kurang menggembirakan, akibat kurangnya sumber daya manusia, sistem operasional yang belum tertata dengan baik dan kurangnya dukungan pemerintah. ${ }^{4}$

Undang-undang perbankan No. 7/1992 tersebut belum memberikan landasan hukum yang kuat terhadap pengembangan bank syarî'ah, karena belum secara tegas mengatur mengenai keberadaan bank berdasarkan prinsip syarî̀ah, melainkan bank bagi

3Sutan Remy Sjahdaeini, Perbankan Islam dan kedudukannya dalam Tata Hukum Perbankan Indonesia (Jakarta: Grafiti, 1999), hlm. 192-193.

4Zainul Arifin, Memahami Bank Syari'ah: Lingkup, Peluang, Tantangan dan Prospek (Jakarta: Alvabet, 2000), hlm.209. 
hasil. Pengertian bagi hasil yang dimaksudkan dalam Undangundang tersebut belum mencakup secara tepat pengertian bank syarî'ah yang memiliki cakupan lebih luas dari bagi hasil. ${ }^{5}$

Selama periode tahun 1992 sampai dengan tahun 1998 perkembangan perbankan syarî'ah menunjukkan suatu kemajuan yang cukup mengembirakan yang ditandai dengan berdirinya perbankan syarî'ah pertama di Indonesia, yaitu PT. BMI pada tahun 1992. Namun, sampai tahun 1998 kemajuan perbankan syarî'ah seakan-akan berjalan di tempat, karena tidak ada lagi pendirian bank syarî'ah baru. Kondisi stagnan ini muncul karena beberapa hal, yaitu: (1) Rendahnya pengetahuan dan kesalahpahaman masyarakat mengenai perbankan syarî'ah; (2) Ketentuan operasional perbankan, intrument moneter dan pasar keuangan syarî'ah yang belum tersedia; (3) Keterbatasan jaringan kantor bank syarî'ah; (4) Kurangnya SDM dan keahlian. ${ }^{6}$

Perkembangan berikutnya, setelah diberlakukan Undangundang No. 10 tahun 1998 tentang perubahan UU No. 7 tahun 1992 tentang perbankan yang diikuti dengan dikeluarkannya sejumlah ketentuan pelaksana dalam bentuk SK Direksi BI/Peraturan Bank Indonesia telah memberikan landasan hukum yang kuat dan kesempatan yang lebih luas bagi pengembangan perbankan syarî'ah di Indonesia. Perundang-undangan tersebut memberikan kesempatan yang luas untuk pengembangan jaringan perbankan syarî'ah antara lain melalui izin pembukaan Kantor Cabang Syari'ah (KCS) oleh bank umum konvensional. Selain itu, UU No. 23 tahun 1999 tetang Bank Indonesia juga menugaskan BI mempersiapkan perangkat peraturan dan fasilitas penunjang yang mendukung operasional bank syarî'ah. ${ }^{7}$

Kedua Undang-undang tersebut di atas menjadi dasar hukum penerapan dual banking system di Indonesia. Dual banking system yang dimaksud adalah terselenggaranya dua sistem perbankan (konvensional dan syarî'ah) secara berdampingan dalam melayani perekonomian nasional yang pelaksanaannya diatur dalam berbagai peraturan perundang-undangan yang berlaku. Pengembangan dual

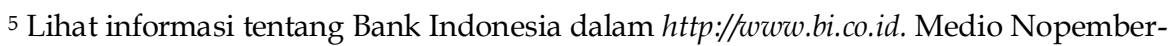
Desember 2000.

6 Bank Indonesia, Perbankan Syari'ah Nasional: Kebijakan dan Perkembangan, Makalah Bank Indonesia, Oktober 2001.

7Ibid. 
banking system sebagaimana yang diamanatkan oleh undang-undang di atas didasarkan atas berbagai pertimbangan, antara lain: Pertama, Pengembangan perbankan syarî'ah pada tahap awal ditujukan untuk memenuhi kebutuhan masyarakat yang menginginkan pelayanan jasa perbankan yang sesuai dengan prinsip syarîah yang diyakini. Dipandang dari sisi kepentingan pembangunan, tersedianya akses pelayanan perbankan bagi segmen masyarakat yang belum terlayani oleh jasa perbankan akan dapat meningkatkan mobilisasi dana masyarakat secara keseluruhan sehingga dapat pula meningkatkan kontribusi mereka dalam pembangunan nasional.

Kedua, Pengalaman krisis perbankan yang terjadi sejak tahun 1998 membuktikan bahwa bank yang beroperasi dengan prinsip syarî'ah dapat bertahan ditengah gejolak nilai tukar dan tingkat suku bunga yang tinggi. Keadaan ini didukung oleh karakteristik kegiatan usaha bank syarî'ah yang melarang bunga bank (ribâa) dan nisbah bagi hasil sebagai penggantinya (profit loss sharing contract), serta melarang transaksi keuangan yang bersifat spekulatif (al-gharar) dan tanpa didasarkan pada kegiatan usaha yang riil. Keberadaan dua sistem perbankan yang berkembang secara paralel (dual banking system) serta mempunyai hubungan keuangan terbatas satu sama lain akan menciptakan diversifikasi resiko keuangan secara lebih beragam, yang akhirnya dapat mengurangi problem system risk pada saat terjadi krisis keuangan. Dengan demikian pengembangan perbankan syarî'ah diharapkan dapat meningkatkan ketahanan sistem perbankan nasional di masa mendatang.

Ketiga, Pengembangan perbankan syarî'ah adalah juga dilakukan dalam rangka pengembangan sistem perbankan alternatif yang memiliki karakteristik dan keunggulan tertentu dibandingkan dengan sistem perbankan konvensional. Unsur moralitas menjadi faktor penting dalam seluruh kegiatan bank syarî'ah, sehingga hal ini dihadapkan pula akan mendorong terciptanya etika usaha dan integritas pemilik dan pengurus yang tinggi. Kontrak pembiayaan yang lebih menekankan sistem bagi hasil mendorong terciptanya pola hubungan kemitraan (mutual investor relationship) bukan pola hubungan debitur-kreditur yang antagonis, sehingga baik pemilik dana, bank maupun pengguna dana mempunyai motivasi yang sama untuk menciptakan kegiatan usaha yang menguntungkan, memperhatikan prinsip kehati-hatian dan berupaya memperkecil 
resiko kegagalan usaha. Sejalan dengan upaya-upaya restruturisasi perbankan yang sedang dilaksanakan saat ini, pengembangan bank syarî'ah diharapkan dapat meningkatkan kualitas sistem perbankan yaitu dengan adanya kompetisi yang sehat yang dapat mendorong terciptanya pelayanan konsumen yang lebih baik.

Keempat, Dalam jangka panjang, dengan berkembangnya bankbank syarî'ah yang sehat dan dapat memberikan jasa pelayanan yang kompetitif akan dapat mendorong peningkatan aliran modal masuk dari investor internasional khususnya dari lembaga atau pihak-pihak yang mempersyaratkan pola transaksi dengan prinsip syarî'ah.

Kelima, Oleh karena kegiatan pembiayaan bank syarî'ah lebih didasarkan pada investasi riil dan participation system maka suplay uang dari sistem perbankan syarî'ah sangat terkait erat dengan kebutuhan transaksi pelaku ekonomi secara riil; alokasi sumber daya keuangan juga merupakan respon langsung terhadap kapasitas produksi dan output sektor riil. Di samping itu dengan prinsip pelarangan kegiatan spekulasi dan transaksi keuangan yang tidak didasarkan pada kegiatan usaha riil maka hal ini dapat mengurangi kecenderungan kondisi pertumbuhan ekonomi semu (buble economic). Karakteristik ini tentu saja secara langsung memberi dampak positif dalam mengatasi problem inflasi. ${ }^{8}$

Dengan diberlakukannya UU No. 10 tahun 1998, maka telah ditetapkan landasan hukum yang kuat serta menjamin adanya kepastian hukum bagi para pelaku ekonomi serta masyarakat luas, untuk kelembagaan dan kegiatan usaha bank syarî'ah meliputi: (1) Pengaturan aspek kelembagaan dan kegiatan usaha bank syarî'ah. Berdasarkan pasal 1 ayat 3 UU no. 10 tahun 1998, bank konvensional dapat membuka cabang usahanya yang berdasarkan syarî'ah atau membuka satuan kerja dan kantor cabang khusus, demikian juga BPR, yang diatur dalam pasal 1 ayat 4, dapat membuka jenis usaha berdasarkan syarî'ah; (2) Pendirian bank syarî'ah. Sebagaimana pasal 16, persyaratan dan tata cara pendirian Bank Umum dan BPR syarî'ah ditetapkan oleh BI; dan (3) Pembukaan kantor cabang syarî'ah. Hal ini didasarkan pada penjelasan pasal 6 huruf $\mathrm{m}$, ditentukan bahwa bank konvensional dapat membuka kantor cabang yang melakukan kegiatan usaha berdasarkan syarî'ah.

8 Ibid. hlm. 1-2. 
Berdasarkan beberapa program pengembangan ini, sampai Agustus 2001, baru terdapat lima bank syarî'ah dengan 44 kantor cabang dan 81 BPRS yang tersebar di seluruh Indonesia. Menurut data BI hingga Agustus 2001 total aset yang dimiliki Bank Syarî'ah sebesar Rp. 2,3 Trilyun atau sekitar 0,22 \% dibanding total aset Bank Umum yang mencapai Rp. 1.015,4 trilyun. Dana pihak ketiga yang dihimpun pada periode yang sama sebesar Rp. 1,5 trilyun atau 0,20\% dari yang dihimpun Bank Umum yang mencapai Rp. 725,5 \%. Sementara untuk aset BPRS hingga Maret 2001 sekitar 128 milyar, dengan volume kredit yang disalurkan mencapai Rp. 92 milyar. Sedangkan dana masyarakat yang berhasil dihimpun sekitar Rp. 7 milyar lebih. ${ }^{9}$

Demikian juga, dengan diberlakukannya UU No. 23/1999, Bank Indonesia dapat melakukan kebijakan moneter berdasarkan Prinsipprinsip syarî'ah, sehingga bank sentral tersebut dapat pula mempengaruhi likuiditas perekonomian melalui bank-bank syarî'ah. Dengan kata lain keberadaan perbankan syarî'ah telah diakui secara utuh dalam sistem perbankan nasional. Dengan berbekal rangkaian kebijakan baru, antar bank syarî'ah dapat melakukan pinjammeminjam uang melalui Pasar Uang Antar-Bank berdasarkan prinsip syarî'ah (PUAS) yang disediakan BI. Sedangkan piranti yang digunakan adalah sertifikat Investasi Mudharabah Antar Bank (IMA). Dengan demikian bagi bank yang memiliki kelebihan dan (bank penanan dana) dapat melakukan investasi kepada bank yang mengalami kekurangan dana (bank penerbit) yang selanjutnya akan menerbitkan sertifikat IMA.

Produk aturan baru lainnya untuk perbankan syarî'ah adalah Sertifikat Wadhiah Bank Indonesia (SWBI). Menurut Setiawan Budi Utomo, Ketua Lembaga Studi dan Pengembangan Islam Yayasan AlAufia Jakarta, SWBI adalah alternatif darurat pengganti Sertifikat Bank Indonesia (SBI) yang dikeluarkan BI.10

Apabila dibandingakan dengan negara-negara lain, seperti Malaysia, yang sudah melakukan pengembangan perbankan syarî'ah sejak tahun 1979, maka Indonesia termasuk lambat dalam

9 Redaktur, "Perkembangan Bank Syari'ah Memprihatinkan", Republika, Jum'at 26 Oktober 2001.

10 Redaktur, "Tegar di Tengah Badai”, Majalah Suara Hidayatullah, Oktober 2000 
mengembangkan perbankan syarî'ah. Hal ini disebabkan beberapa faktor antara lain: (1) Adanya perbedaan pandangan di kalangan ulamâ Indonesia mengenai bunga bank. Pendapat para ulamâ tersebut secara garis besar terbagi dalam tiga pendapat, yaitu; haram, subhat dan halâl; (2) Pertimbangan kondisi sosio-politik di Indonesia yang kurang kondusif bagi perkembangan bank syarî'ah. Dalam kaitan ini, belum adanya political-will dari pemerintah dan tingkat heterogenitas masyarakat Indonesia yang cukup tinggi, terutama dari sisi heterogenitas agama dan pemahaman keagamaan, merupakan faktor penghambat yang cukup signifikan menuju komitmen yang harus dipikul mereka dengan pencantuman label "syarî'ah"; (3) Adanya kendala dasar hukum yang belum memungkinkan bagi pengembangan perbankan syarî'ah, di mana dalam Undang-undang No. 14 tahun 1967 tentang pokok-pokok perbankan tidak dikenal adanya bank syarî'ah;'11 (4) Pemahaman masyarakat Muslim sendiri yang masih belum tepat terhadap kegiatan operasional bank syarî'ah; (5) Peraturan perbankan yang berlaku belum sepenuhnya mengakomodasi operasional bank syarî'ah, misalnya untuk mengatasi masalah likuiditas; instrument moneter yang sesuai dengan prinsip syarî'ah untuk keperluan tugas bank sentral yang mencakup standar akutansi, audit, pelaporan, dan sebagainya; (6) Jaringan kantor bank syarî'ah yang belum luas; dan (7) Sumber daya manusia yang memiliki keahlian mengenai bank syarî'ah masih sedikit ${ }^{12}$.

Ketujuh faktor di atas memang cukup berpengaruh bagi lambatnya perkembangan bank syarî'ah di Indonesia. Namun untuk mengetahui perkembangannya secara lebih mendetail, perlu adanya penelitian lebih lanjut. Sebagai sebuah pemahaman awal, pada bagian berikut ini akan digambarkan persepsi Umat Muslim Indonesia tentang bank syarî'ah.

Persepsi Umat Muslim terhadap Bank Syarî'ah: Hasil Penelitian di 4 (empat) Wilayah di Indonesia

Berdasarkan penelitian yang dilakukan oleh Bank Indonesia di 4 (empat) wilayah di Pulau Jawa yang terdiri dari wilayah Jawa Barat

11Bank Indonesia, Perbankan, hlm.2.

12 Muhammad Syafi'i Antonio, Bank Syari'ah dari Teori ke Praktek (Jakarta: Gema Insani Pres, 2001), hlm. 224-226. 
bekerjasama dengan LP-IPB Bogor, wilayah Jawa Tengah dan Daerah Istimewa Yogyakarta bekerjasama dengan LP-UNDIP Semarang, wilayah Jawa Timur bekerjasama dengan PPBEI-FE-UNIBRAW Malang, dapat disajikan hasilnya sebagai berikut: 13

1. Lebih dari 4000 responden yang tersebar di 4 propinsi di Pulau Jawa tersebut, sebagian besar, tepatnya lebih dari $95 \%$ berpendapat bahwa sistem perbankan merupakan sesuatu penting dan dibutuhkan dalam mendukung kelancaran transaksi ekonomi;

2. Kesan umum yang ditangkap oleh masyarakat tentang bank syarî'ah adalah bahwa (1) bank syarî'ah identik dengan bank dengan sistem bagi hasil, (2) bank syarî'ah adalah bank yang Islamî, namun berdasarkan survey yang dilakukan di wilayah Jawa Barat, 8,1 \% pihak responden menyatakan bahwa bank syarî'ah secara eksklusif hanya diperuntukkan bagi umat Muslim.

3. Pandangan masyarakat mengenai sistem bunga adalah sebagai berikut:

a. Untuk responden wilayah Jawa Timur, sebanyak 10,2\% responden menyatakan bahwa bank syarî'ah sama saja dengan bank konvensional dan 16,5\% menyatakan bahwa bagi hasil sama saja dengan bunga. Namun demikian, sebanyak $94 \%$ berpandangan bahwa sistem bagi hasil adalah sistem yang dinilai universal dan dapat diterima karena bersifat menguntungkan baik bagi bank maupun bagi nasabah;

b. Untuk wilayah Jawa Barat, sebanyak $62 \%$ responden menyatakan bahwa sistem bunga bertentangan dengan ajaran Islam, sedangkan 22\% tidak bertentangan dengan ajaran Islam, dan 16\% menyatakan tidak tahu. Untuk wilayah Jawa Tengah dan Daerah Istimewa Yogyakarta, sebanyak $48 \%$ responden menyatakan bahwa sistem bunga bank bertentangan dengan agama Islam, 21\% tidak bertentangan dengan ajaran Islam, dan 31\% menyatakan

13 Bank Indonesia, Ringkasan Pokok-pokok hasil penelitian potensi, Preferensi dan Perilaku Masyarakat terhadap Bank Syari'ah di Pulau Jawa, (Jakarta: Direktorat Penlitian Dan Pengaturan Perbankan, 2000). Hasil penelitian tidak diterbitkan.. 
tidak tahu. Terakhir, untuk wilayah Jawa Timur, sebanyak $31 \%$ responden mengatakan sistem bunga bank tersebut bertentangan dengan ajaran Islam dan 69\% mengatakan tidak bertentangan dengan ajaran Islam.

4. Pengetahuan masyarakat mengenai sistem perbankan syarî'ah relatif tinggi, misalnya di Jawa Barat sebanyak $88,6 \%$ dan di Jateng-DIY sebanyak 71,2\%) mengaku memahami tentang sistem perbankan syarî'ah. Meskipun demikian, pemahaman mengenai keunikan sistem produk dan jasa bank syarî'ah secara umum masih rendah;

5. Analisis terhadap faktor-faktor yang memotivasi masyarakat untuk menggunakan jasa perbankan syarî'ah ternyata untuk masyarakat Jawa Barat dan Jawa Timur yang lebih dominan adalah karena faktor kualitas pelayanan dan kedekatan lokasi bank dari pusat kegiatan. Sedangkan faktor pertimbangan keagamaan (hukumnya), bukanlah menjadi faktor penting dalam mempengaruhi kecenderungan menggunakan jasa bank syarî'ah. Namun, sebaliknya, untuk masyarakat Jawa Tengah faktor pertimbangan agama adalah motivator terpenting yang mendorong mereka menggunakan jasa bank syarî'ah;

6. Dari penelitian wilayah Jawa Barat diperoleh informasi bahwa masyarakat non nasabah bank syarî'ah yang diberi penjelasan sistem poduk dan jasa serta kehalalan bank syarî'ah mempunyai kecenderungan kuat memilih bank syarî'ah. Namun sebaliknya, nasabah yang telah menggunakan jasa bank syarî'ah, sebagian memiliki kecenderungan untuk berhenti jadi nasabah. Ini disebabkan, antara lain, karena kualitas pelayanan yang kurang baik dan atau keraguan akan konsistensi penerapan prinsip syarî'ah.

Dari beberapa persepsi masyarakat tentang bank syarîa di atas, terutama berkenaan dengan motivasi mereka dalam menggunakan jasa perbankan syarî'ah ternyata lebih banyak didorong oleh hal-hal yang bersifat teknis, seperti kedekatan dengan pusat kegiatan, bukan karena dorongan keagamaan. Tentu saja, hal ini menjadi tugas berat pelaku perbankan syarî'ah untuk merangkul cendekiawan Muslim dalam upaya memengaruhi dan "merayu" umat 
Sofyan Hadi

Muslim Indonesia agar menggunakan jasa dan produk perbankan syarî'ah.

\section{Perkembangan Asuransi Takâful di Indonesia}

Selain perkembangan lembaga keuangan sebagaimana dijelaskan di atas, dapat pula disaksikan berdirinya lembaga asuransi Islam, yakni asuransi takâful pada 1994. Lembaga ini berperan sebagai lembaga penanggungan resiko (risk bearing) atau penanggungan ketidaktentuan dan kekhawatiran (uncertainty) yang beroperasi dengan sistem bagi hasil (mudlarabah) dan kebaikan (tabarru)14. TEPATI merealisasikan berdirinya PT. Syarikat Takaful Indonesia sebagai holding company dan dua anak perusahaannya, yaitu PT. Asuransi Takaful Keluarga (Asuransi Jiwa) dan PT. Asuransi Takaful Umum (Asuransi Kerugian). Dibentuknya kedua lembaga asuransi tersebut adalah untuk mengikuti ketentuan UU No. 2 tahun 1992 tentang usaha perasuransian, di mana perusahaan asuransi jiwa dan perusahaan kerugian harus didirikan secara terpisah. Tugas holding company selanjutnya adalah mengembangkan keuangan syarî'ah lainnya, antara lain leasing, anjak piutang, modal ventura, pegadaian, dan sebagainya. Dalam hal ini fungsi utama asuransi takâful adalah sebagai invesment company. 15

Takâful ini didirikan bertumpu pada konsep wa ta'âwanu 'alâ albirr wa al-taqwâ dan al-ta'min, yang menjadikan semua peserta asuransi sebagai keluarga besar yang saling menjamin dan menanggung resiko satu sama lain. Dalam hal ini, takâful meniadakan unsur al-gharar, al-maysir dan ribâ. Perusahaan asuransi yang berdasarkan saling menanggung (takâful) satu sama lain atas musibah yang diderita saudaranya ini dari tahun ke tahun terus berusaha meningkatkan kulitas kinerjanya. Menurut Direktur Utama Takaful, Iwa Sewaka, kini asuransi takâful keluarga telah memiliki kekayaan sekitar Rp. 54 milyar, sedangkan asuransi takâful umum telah memiliki kekayaan Rp. 33 milyar dan akumulasi premi Rp. 71 milyar. Adapun peserta asuransi takâful keluarga kini telah mencapai 450 ribu orang. Sehingga asuransi tersebut telah masuk dalam peringkat

${ }^{14}$ A.M. Saefuddin, "Iftitah Asuransi Islam", Jurnal Ulumul Qur'an Vol. VII No. 2 (1996), hal. 3

15 Redaksi Ulumul Qur'an, "Syarikat", hlm 36-37. 
sepuluh besar industri asuransi jiwa di Indonesia dari segi kepesertaannya. ${ }^{16}$

Sejak April 2000, PT. Syarikat Takaful Indonesia, perusahaan induk dari asuransi takâful umum dan asuransi takâful keluarga mencanangkan pola baru pemasaran jasa asuransi berupa jalinan kerja sama dan kemitraan yang disebut Takâful Networking. Mitra yang dijadikan sasaran adalah Koperasi Pondok Pesantren (Kopontren), Bank Perkreditan Rakyat (BPR) Syarî'ah, serta Badan Amil, Zakat, Infak dan Sadaqah (BAZIS). Untuk mendukung program tersebut, asuransi takâful telah merencanakan untuk membuka kantorkantor baru yang disebut underwritting office takâful di enam kota besar, yaitu Bandung, Surabaya, Semarang, Medan, Samarinda dan Jakarta. Selanjutnya dari keenam UOT tersebut akan hadir gerai Takaful Authorized Agency (TAA) sebanyak 330 kantor dengan 3.300 karyawan. Dengan jaringan kerjasama seperi itu diproyeksikan pada tahun 2004, akan tercipta 14.755 gerai takâful di seluruh Indonesia, sehingga terbuka peluang kerja bagi 147.550 orang tenaga kerja baru dari kalangan umat. Dengan program tersebut, Iwa Sewaka optimis bahwa perusahaan yang dipimpinnya itu akan mampu mengumpulkan pendapatan premi sebesar Rp. 3,5 trilyun. ${ }^{17}$

Dalam perkembangannya, pemerintah mengatur operasional asuransi. Dengan maksud untuk melindungi konsumen dari terjadinya kecurangan perusahaan. Adanya batas rasio modal terhadap premi terkumpul telah menyebabkan beberapa perusahaan masuk dalam kategori insolvent. Saat ini modal dasar perusahaan asuransi baru minimal Rp. 100 milyar. Peraturan pemerintah yang masih menjadi kendala bagi asuransi syarî'ah adalah dalam hal lahan investasi. Perusahaan asuransi dilarang berinvestasi di pasar modal luar negeri. Kondisi itu membatasi kesempatan perusahaan untuk diversifikasi resiko dan kemungkinan mendapatlkan keuntungan lain. Untuk asuransi syarî'ah, simpanan berjangka/deposito hanya boleh pada bank syarî'ah. Di Indonesia belum ada pasar uang syarî'ah. ${ }^{18}$

16 Lihat laporan Suara Hidayatullah, edisi Oktober 2000

17 Ibid.

${ }^{18}$ Agus Haryadi, “Prospek Bisnis : Asuransi Syari'ah Takaful” Jurnal Ulumul Qur'an, Vol. III No. 5, (Pebruari 2000). 
Sebagaimana halnya lembaga keuangan lain, diperlukan tiga unsur pokok dalam pengembangan bisnis asuransi syarî'ah, yaitu: (1) Adanya sumber daya manusia yang profesional dan mempunyai komitmen keislaman yang tinggi; (2) Tersedianya modal yang memadai; dan (3) Dapat diterapkannya sistem operasi yang sesuai. ${ }^{19}$

\section{Pengelolaan dan Produk Asuransi Takâful}

Sebagaimana disebutkan di atas, terdapat dua lembaga asuransi takâful di Indonesia, yakni PT. Asuransi Takaful Umum dan PT. Asuransi Takaful Keluarga. Dalam PT. Asuransi Takaful Umum, seluruh premi takâful yang dibayar dimasukkan ke dalam rekening derma, yaitu rekening yang digunakan untuk membayar klaim (manfaat takâful) kepada peserta. Uang angsuran premi takâful akan dimasukkan ke dalam "Kumpulan Dana Peserta", untuk diinvestasikan berdasarkan syarî'ah. Keuntungan yang diperoleh akan dimasukkan ke dalam "Kumpulan Dana Peserta". Pembayaran klaim dan biaya yang diperlukan oleh perusahaan akan diambil dari "Kumpulan Dana Peserta". Jika terdapat kelebihan sisa, dana tersebut akan dibagikan kepada peserta yang tidak mengajukan klaim menurut prinsip mudlarabah.

Sedangkan dalam PT. Asuransi Takaful Keluarga, setiap premi takâful yang dibayar, dibagi ke dalam dua rekening, yaitu: (1) rekening tabungan, yang merupakan rekening tabungan peserta, dan (2) rekening derma/tabarru, yaitu rekening yang digunakan untuk membayar klaim (manfaat takâful) kepada ahli waris, jika peserta ditakdirkan meninggal dunia sebelum pertanggungan berakhir. Uang angsuran premi akan disatukan ke dalam "Kumpulan Dana Peserta" untuk diinvestasikan ke dalam pembiayaan-pembiayaan proyek yang dibenarkan secara syarî'ah. Keuntungan yang diperoleh akan dibagikan sesuai dengan perjanjian mudlarabah yang telah disepakati sebelumnya. Misalnya $60 \%$ untuk peserta dan $40 \%$ untuk perusahaan. Bagian keuntungan peserta akan dikreditkan ke rekening tabungan dan rekening derma secara proporsional.

PT. Asuransi Takaful Umum mempunyai beberapa produk, di antaranya, berupa Takâful Kendaraan Bermotor, Takâful Kebakaran, Takâful Risiko Bangunan, Takâful Risiko Pemasangan, Takâful Mesin,

${ }^{19} \mathrm{Ibid}$. 
Takâful Peralatan Elektronik, Takâful Pengangkutan Barang, Takâful Rangka Kapal, Takâful Pengangkutan Uang, Takâful Gabungan, Takâful Kecelakaan Diri, Takâful Penyimpanan Uang, Takâful Tanggungan Gugat, Takâful Kebongkaran, Takâful Pemilik dan penghuni rumah, Takâful Kehilangan Keuntungan Akibat Kerusakan Mesin, Takâful Kehilangan Akibat Kebakaran, Takâful Peralatan Konstruksi, dan Takâful Lampu Reklame

Sedangkan PT. Asuransi Takaful Keluarga mempunyai produk, antara lain, Takâful Dana Investasi, Takâful Dana Siswa, Takâful Dana Haji, Takâful al-Khairat, Takâful Kesehatan, Takâful Majeli Ta'lim, Takâful Wisata dan Umrah, Takâful Perjalanan Haji, dan Takâful Kecelakaan Diri.

\section{Tantangan Takâful Indonesia di Era Globalisasi: Sebuah Refleksi}

Kehadiran lembaga keuangan syarî'ah di Indonesia dimungkinkan terutama karena faktor kondisi politik yang lebih akomodatif terhadap aspirasi umat Muslim di ujung 1990. Salah satu wujudnya adalah berdirinya Ikatan Cendekiawan Muslim Indonesia (ICMI) pada Desember 1990. ICMI kemudian sangat berperan terhadap proses lahirnya Bank Muamalat Indonesia (BMI). Kehadiran BMI selanjutnya diikuti dengan semaraknya pendirian Bank Perkreditan Rakyat Syari'ah (BPRS), baik oleh organisasi Islam maupun para individu Muslim di seluruh pelosok tanah air.

Ditinjau dari segi waktu, kehadiran sistem keuangan syarî'ah di Indonesia sangat tepat karena bersamaan dengan momentum tahap penyelesaian pembangunan dua puluh lima tahun pertama. Keberhasilan pembangunan telah meningkatkan derajat kehidupan bangsa secara keseluruhan, terlepas dari berbagai kekurangan yang masih ada di dalamnya. Dengan melihat potret bangsa Indonesia di masa mendatang sebagaimana di maksud di atas, hal itu akan mendorong terjadinya peningkatan kebutuhan atas berbagai jasa keuangan yang makin canggih. Salah satunya adalah jasa asuransi.

Kehadiran Syarikat Takaful Indonesia Asuransi Takaful, yang disponsori oleh Yayasan Abdi Bangsa atau ICMI, dengan demikian memiliki landasan yang kuat dan penting, terutama bila dikaitkan dengan kondisi objektif untuk menampilkan Islam dalam dimensi yang lebih luas. Asuransi takâful sebagai lembaga asuransi yang berlandaskan ajaran Islam, insyaallâh akan mampu menjadi sarana 
yang dapat diandalkan dalam mobilisasi dana masyarakat bagi pembiayaan pembangunan secara jangka panjang.

Dalam suatu masyarakat, setidaknya ada dua variabel penting dalam proses akumulasi modal (capital accumulation). Variabel pertama adalah masyarakat (umat) itu sendiri sebagai salah satu sumber dana, yang biasanya dikumpulkan melalui suatu institusi resmi. Variabel yang kedua adalah institusi itu sendiri dalam hal ini diwakili oleh takâful yang secara langsung maupun tidak langsung akan bertindak sebagai perantara antara satu anggota masyarakat dengan masyarakat lainnya. Kedua variabel ini, seperti telah disinggung di atas, akan sangat dipengaruhi oleh kenaikan pendapatan dan kemakmuran suatu masyarakat serta tingkat pendidikan sehingga antara demand dan supply akan bertemu pada suatu titik keseimbangan (equilibrium).

Setidaknya ada dua komponen penting yang bisa disumbangkan oleh takâful dalam proses pembangunan. Pertama, takâful merupakan lembaga yang diupayakan sebagai sarana pengumpulan dana dari masyarakat. Dana ini sebagian besar kemudian diinvestasikan lagi kepada bank, yang juga beroperasi berdasarkan syarî'ah Islam. Kedua, adanya unsur mudharabah yang merupakan suatu sistem bagi hasil dan surplus yang bisa dinikmati oleh peserta takâful dalam setiap akhir tutup buku. Komponen ini tidak pernah ada dalam asuransi konvensional. Kalaupun ada, ia tidak lebih dari sebagai no claim bonus yang kadang-kadang jumlahnya tidak begitu besar. Namun satu hal yang perlu di catat adalah bahwa eksistensi takâful sebagai suatu institusi yang berdasarkan syarî'ah, haruslah didukung oleh keberadaan institusiinstitusi keuangan lainnya, yang juga beroperasi berdasarkan syarî'ah Islam.

Memasuki abad informasi dan globalisasi, dunia ini dirasakan demikian kecil dan tanpa batas (boderless). Situasi tersebut tercipta berkat kemajuan di bidang teknologi informasi yang demikian canggih. Asuransi takâful tentunya juga harus melakukan berbagai penyesuaian, baik dari segi permodalan, sistem teknologi, maupun sumber daya manusianya. Ditinjau dari segi konsep, takâful cukup dapat diandalkan karena memiliki berbagai keunggulan dan banyak pihak telah mengakuinya. 
Strategi yang perlu ditempuh untuk menjadikan takâful mampu menghadapi persaingan secara global, pada dasarnya mencakup hal-hal berikut: Pertama, Pembuktian atas keunggulan konsep STI, tidak saja ditujukan kepada umat Muslim tetapi juga kepada keseluruhan umat manusia. Kedua, menjadikan takâful sebagai unit usaha yang dimiliki dan menjadi kebanggaan seluruh umat Muslim. Ketiga, peningkatan kualitas sumber daya manusia, pengembangan sistem, dan penyempurnaan organisasi secara sistematis dan berkesinambungan ${ }^{20}$.

Tantangan utama bagi upaya pengembangan takâful adalah peranan umat Muslim di bidang ekonomi yang relatif masih belum besar dan luas. Keadaan tersebut tentu tidak seimbang dengan kedudukan umat Muslim sebagai kelompok mayoritas di negeri ini. Selain itu, sikap ambivalen sebagian besar masyarakat Muslim terhadap konsep ekonomi berdasarkan syarî'ah juga masih menonjol. Umat Muslim masih lebih terbiasa dengan pola ekonomi yang sekular sifatnya. Padahal, pada era globalisasi ini takâful memiliki kemampuan untuk mempertahankan eksistensinya. Konsepnya yang memiliki berbagai keunggulan, secara bertahap akan diterima oleh dunia Internasional.

\section{Penutup}

Di Indonesia, perkembangan bank syarî̀ah dan takâful mengalami perkembangan yang sangat pesat dan memberi pengaruh yang luas terhadap perbaikan ekonomi umat dan kesadaran baru untuk mengadopsi dan ekspansi lembaga keuangan Islam, dengan menggunakan instrumen sistem bagi hasil (mudlarabah, profit and lost sharing) sebagai pengganti sistem bunga. Pada satu saat Islam bersama umatnya bangkit tampil ke permukaan dan pada saat yang lain tenggelam, sebagaimana bergilirnya waktu siang dan malam. Mengamati perkembangan bank syarî'ah dan takâful dan kemajuan lembaga keuangan yang lain BMI, BPRS, BMT yang berjalan bersama dengan institusi sejenis yang konvensional, yang sejak lama sudah berjalan lebih dulu, kita berharap agar terjadi persaingan yang sehat dan jujur (fastabiqû al-khayrât). Sehingga pada saatnya, kita dapat

${ }^{20}$ M. Dawam Rahardjo, "Takaful dan Tantangan Globalisasi", Jurnal Ulumul Qur'an, Vol. VII No. 2 (1996), hlm. 38-41 
menyaksikan bahwa ekonomi sistem bagi hasil dapat tampil lebih bersinar menerangi ekonomi umat ketimbang ekonomi sistem bunga.

Untuk itu, kita perlu memikirkan dan mengkaji berbagai kemungkinan dan kelayakan berdirinya bank-bank Islam dan lembaga asuransi Islam lainnya di Indonesia, selain yang sudah ada sekarang ini. Ini dilakukan agar tercipta persaingan yang mengarah pada terbentuknya efisiensi, dimana produk-produk halal dalam bidang keuangan ini berdaya saing dan berdaya banding tinggi. Dengan kata lain, produk halal dari bank atau lembaga asuransi Islam (takâful) tidak harus mahal. Sekali lagi, tidak boleh ada image terbentuk bahwa yang halal itu harus mahal.

\section{Daftar Pustaka}

Antonio, Muhammad Syafi'i. Bank Syari'ah dari Teori ke Praktek. Jakarta: Gema Insani Pres, 2001.

Arifin, Zainul. Memahami Bank Syari'ah : Lingkup, Peluang, Tantangan dan Prospek. Jakarta: Alvabet, 2000.

Bank Indonesia, dalam http ://www.bi.co.id. medio NopemberDesember 2000.

Bank Indonesia, Ringkasan Pokok-pokok Hasil Penelitian Potensi, Preferensi (Jakarta: Direktorat Penelitian Perbankan, 2000).

Bank Indonesia, Perbankan Syari'ah Nasional: Kebijakan dan Perkembangan, Makalah Bank Indonesia, Oktober 2001.

Haryadi, Agus. "Prospek Bisnis : Asuransi Syari'ah Takaful" Jurnal Ulumul Qur'an, Vol. III No. 5 (Februari, 1991).

Rahardjo, M. Dawam. "Takaful dan Tantangan Globalisasi". Jurnal Ulumul Qur'an, Vol. VII No. 2 (1996).

Redaksi Hidayatullah, "Tegar di Tengah Badai", Majalah Suara Hidayatullah, (Oktober 2000).

Redaktur, "Perkembangan Bank Syari'ah Memprihatinkan", Republika, Jum'at 26 Oktober 2001.

Saefuddin, A.M., "Iftitah Asuransi Islam", Jurnal Ulumul Qur'an, Vol. II No. 2 (1996).

Sjahdaeini, Sutan Remy. Perbankan Islam dan Kedudukannya Dalam Tata Hukum Perbankan Indonesia. Jakarta: Grafiti, 1999.

Triyumono, Iwan. "Ekonomi Islam, Ekonomi Riil", Jurnal Ulumul Qur'an, Vol. VII No. 2 (1996). 